\title{
Research on Management Defense and Enterprise Innovation under Informatization
}

\author{
Jingjing Kang ${ }^{a^{*}}$ \\ Lanzhou University of Technology, School of Economics and Management, Lan Zhou, Gan Su, 730050
}

\begin{abstract}
ABSRTACT: The information development affects the Enterprise Management Defense, and then affects the enterprise innovation. This paper takes the non-financial listed companies in China's A-share market from 2013 to 2017 as samples to empirically study the impact of management defense on enterprise innovation. It is found that managerial defense inhibits enterprise innovation; compared with non-state-owned enterprises, managerial defense of state-owned enterprises has a more significant inhibitory effect on enterprise innovation. The results of this paper provide a basis for improving corporate governance structure, weakening management defense, promoting enterprise innovation, and help government departments deepen the reform of state-owned enterprises.
\end{abstract}

\section{Introduction}

Based on the theory of separation of two rights, when there is a conflict of interest between managers and shareholders, managers will take management defensive behavior in order to maintain their own job security and maximize their own interests ${ }^{[1]}$. Management defense is a common phenomenon in China's Listed Companies, and it has an important impact on the company's capital structure, investment efficiency and dividend policy. Some scholars have found that management defense can cause short-sighted investment, leading to enterprises to reduce $\mathrm{R} \& \mathrm{D}$ Investment ${ }^{[2]}$. There are also studies that show that in order to ensure the safety of their positions and maximize their effectiveness, managers will have risk aversion behavior, leading to the reduction of enterprise risk-taking level ${ }^{[3]}$. The above analysis shows that management defense may indirectly affect enterprise innovation from R \& D investment, enterprise risk-taking, innovation enthusiasm and other aspects, but few scholars directly investigate the impact of management defense on enterprise innovation from the perspective of innovation output.

This paper takes the number of patent applications of A-share listed companies from 2013 to 2017 as the analysis object, empirically tests the impact of management defense on enterprise innovation ability, and examines the moderating effect of institutional investor research. Compared with previous studies, the contributions of this paper are as follows: first, from the perspective of innovation output, it proves the inhibitory effect of managerial defense on enterprise innovation, enriches the relevant literature on managerial defense and enterprise innovation, helps enterprises to improve the governance mechanism, inhibit managerial defense behavior, and promote enterprise innovation and long-term development; second, it distinguishes the nature of enterprises, and finds the relationship between managerial defense and enterprise innovation. The difference of enterprise innovation relationship between state-owned enterprises and non-state-owned enterprises provides the basis for deepening the reform of state-owned enterprises and improving the innovation ability of state-owned enterprises.

\section{Theoretical Analysis and Research Hypothesis}

Management defense refers to the behavior that the management chooses to consolidate their own position security and pursue the maximization of personal utility under the pressure of internal and external control mechanism of the enterprise. Due to the separation of the two rights and the existence of moral hazard, there is information asymmetry between the management and the shareholders. The management has more internal information about the company's operation than the shareholders. When there is a conflict of interest between the management and the shareholders, there will be defensive behavior of the management, which will damage the interests of the enterprise or shareholders ${ }^{[4]}$. In addition, according to the risk aversion hypothesis, managers with management defense motivation also have a stronger risk aversion tendency, in order to reduce the risks faced by their positions and their own interests [3], but it will lead to the reduction of enterprise risk-taking level. Because innovation itself has a certain risk, the reduction of risk-taking level will weaken the enthusiasm of enterprise innovation. However, innovation activities are the basis for enterprises to gain market competitive advantage, and the innovation ability

* Corresponding author: ${ }^{a}$ 674697707@qq.com 
of enterprises represents the future development potential of enterprises, which is in line with the long-term interests of enterprises and shareholders. To sum up, management defensive behavior is not conducive to enterprise innovation, and will damage the interests of enterprises and shareholders. Based on the above analysis, the following hypotheses are put forward:

H1: There is a negative correlation between managerial defense and enterprise innovation, that is, the enhancement of managerial defense will reduce enterprise innovation.

Management defense is a common phenomenon in China's listed companies, but in the context of China's special system, there are great differences in management defense among enterprises with different property rights $^{[2]}$.First of all, compared with non-state-owned enterprises, state-owned enterprises need to undertake more policy tasks, and executives of state-owned enterprises will more consider the influence of political factors when making business decisions ${ }^{[5]}$. Secondly, state-owned enterprise executives are directly appointed by the government and have a short term of office. In order to meet the needs of government assessment in a short period of time and strive for promotion opportunities, they will pay more attention to short-term economic benefits and their own political goals in the business process, while non-state-owned enterprise executives are less affected by political factors and pay more attention to the long-term benefits and profit promotion of the enterprise ${ }^{[6]}$. Thirdly, the compensation of state-owned enterprise executives can not benefit from the huge benefits brought by innovation due to the influence of "salary limit order". Therefore, compared with non-state-owned enterprise executives, state-owned enterprise executives have stronger management defense motivation. The owners of non-state-owned enterprises control the enterprises, so the supervision of the managers of state-owned enterprises is weaker than that of non-state-owned enterprises. Based on the above analysis, the following hypotheses are put forward:

H2: Compared with non-state-owned enterprises, the negative correlation between managerial defense and enterprise innovation is more significant.

\section{Research Design}

\subsection{Sample Selection and Data Sources}

Based on the sample of China's A-share listed companies from 2013 to 2017, this paper conducts the following screening according to the research practice: (1) excluding ST and * ST companies; (2) excluding financial companies; (3) excluding the samples with missing values in the observation samples; (4) in order to avoid the influence of extreme values, $1 \%$ and $99 \%$ Winsor treatment is carried out for all continuous variables in the samples; (5) according to the nature of the actual controllers of listed companies The samples are divided into state-owned and non-state-owned enterprises. After screening, 4998 effective observations were obtained. The above survey data of institutional investors are from wind database, and other data are from CSMAR database. Stata 15.0 statistical analysis software is used for data processing and empirical analysis.

\subsection{Variable Definition}

(1) Management defense (MEI). This paper uses Li Bingxiang et al. (2018) ${ }^{[7]}$ as reference to the construction of management defense index. Without considering external control mechanism, the construction of defense degree variable of management is shown in Table 1. Six variables are selected from three aspects: personal characteristics of managers, incentive mechanism of managers and constraint mechanism of managers. The average value of these six variables is taken as the indicator of the defense level of management Mark, i.e. $\mathrm{MEI}=($ Age + Degree + Tenure + Share + Independent + Dua) $/ 6$

Table 1 Construction of Management Defense Index

\begin{tabular}{|c|c|c|}
\hline $\begin{array}{c}\text { Variable } \\
\text { classification }\end{array}$ & Variable name & Variable definition \\
\hline \multirow{3}{*}{$\begin{array}{c}\text { Personal } \\
\text { characteristics } \\
\text { of managers }\end{array}$} & $\begin{array}{l}\text { Age of general } \\
\text { manager }\end{array}$ & $\begin{array}{l}0 \text { for those under } 45 \\
\text { years old; } 1 \text { for those } \\
\text { between } 45 \text { and } 55 \\
\text { years old; } 2 \text { for those } \\
\text { over } 55 \text { years old }\end{array}$ \\
\hline & $\begin{array}{c}\text { Degree of general } \\
\text { manager }\end{array}$ & $\begin{array}{l}2 \text { for specialty and } \\
\text { below; } 1 \text { for } \\
\text { undergraduate course; } \\
0 \text { for master's degree } \\
\text { and above }\end{array}$ \\
\hline & $\begin{array}{c}\text { Tenure of general } \\
\text { manager }\end{array}$ & $\begin{array}{c}0 \text { for less than } 3 \text { years, } \\
1 \text { for } 3 \text { to } 6 \text { years and } 2 \\
\text { for more than } 6 \text { years }\end{array}$ \\
\hline $\begin{array}{l}\text { The } \\
\text { characteristics } \\
\text { of incentive } \\
\text { mechanism of } \\
\text { managers }\end{array}$ & $\begin{array}{l}\text { Shares held by } \\
\text { general manager }\end{array}$ & $\begin{array}{l}\text { If the shareholding } \\
\text { ratio is greater than } 0 \text {, } \\
\text { take } 0 \text {; if the } \\
\text { shareholding ratio is } 0 \text {, } \\
\text { take } 2\end{array}$ \\
\hline \multirow{2}{*}{$\begin{array}{c}\text { The } \\
\text { characteristics } \\
\text { of manager } \\
\text { restraint } \\
\text { mechanism }\end{array}$} & $\begin{array}{l}\text { Proportion of } \\
\text { independent } \\
\text { directors }\end{array}$ & $\begin{array}{l}2 \text { for less than } 30 \%, 1 \\
\text { for } 30 \% \text { to } 40 \% \text { for } 0 \\
\text { for more than } 40 \%\end{array}$ \\
\hline & $\begin{array}{l}\text { The chairman and } \\
\text { the general } \\
\text { manager are in one } \\
\text { position }\end{array}$ & $\begin{array}{l}\text { If the general manager } \\
\text { concurrently serves as } \\
\text { the chairman of the } \\
\text { board, the assignment } \\
\text { is } 2 \text {; otherwise, it is } 0\end{array}$ \\
\hline
\end{tabular}

(2)Enterprise innovation (INNO). Referring to Zhou Donghua et al. (2019) ${ }^{[8]}$ for the definition of enterprise innovation (INNO) variable, this paper uses the natural logarithm of the number of patent applications plus one to measure enterprise innovation.

(3) Control variables. Referring to the relevant literature, this paper selects the company size (size), asset liability ratio (Lev), return on equity (ROE), growth opportunity (growth), investment opportunity (tobinq), equity concentration (first), board size (b size), enterprise establishment period (age), year factor, industry factor as 
the control variables. The details are shown in Table 1.

Table 2 Variable Definition

\begin{tabular}{|c|c|c|}
\hline Variable name & Variable code & Definition \\
\hline $\begin{array}{l}\text { Enterprise } \\
\text { innovation }\end{array}$ & INNO & $\begin{array}{l}\ln (\text { Number of patent } \\
\text { applications }+1)\end{array}$ \\
\hline $\begin{array}{l}\text { Management } \\
\text { defense }\end{array}$ & MEI & See Table 1 \\
\hline Company size & Size & $\begin{array}{c}\text { Natural logarithm of } \\
\text { total assets at the end } \\
\text { of the year }\end{array}$ \\
\hline $\begin{array}{l}\text { Asset liability } \\
\text { ratio }\end{array}$ & Lev & $\begin{array}{c}\text { Total liabilities / Total } \\
\text { assets }\end{array}$ \\
\hline $\begin{array}{l}\text { Return on net } \\
\text { assets }\end{array}$ & Roe & $\begin{array}{l}\text { Net profit / balance of } \\
\text { shareholders' equity }\end{array}$ \\
\hline $\begin{array}{l}\text { Growth } \\
\text { opportunities }\end{array}$ & Growth & $\begin{array}{l}\text { Growth rate of } \\
\text { operating revenue } \\
\text { (amount of operating } \\
\text { revenue in current } \\
\text { period of this year - } \\
\text { amount of operating } \\
\text { revenue in the same } \\
\text { period of last year) / } \\
\text { (amount of operating } \\
\text { revenue in the same } \\
\text { period of last year) }\end{array}$ \\
\hline $\begin{array}{l}\text { Investment } \\
\text { opportunity }\end{array}$ & TobinQ & $\begin{array}{l}\text { Market value / total } \\
\text { assets }\end{array}$ \\
\hline $\begin{array}{l}\text { Ownership } \\
\text { concentration }\end{array}$ & First & $\begin{array}{l}\text { Shareholding ratio of } \\
\text { the largest shareholder }\end{array}$ \\
\hline Board size & Bsize & $\begin{array}{c}\ln \text { (number of } \\
\text { directors) }\end{array}$ \\
\hline $\begin{array}{c}\text { Years of } \\
\text { establishment }\end{array}$ & Age & $\begin{array}{l}\text { Difference between } \\
\text { sample year and } \\
\text { establishment year }\end{array}$ \\
\hline $\begin{array}{l}\text { Particular year } \\
\text { Industry }\end{array}$ & $\begin{array}{c}\text { Year } \\
\text { Industry }\end{array}$ & $\begin{array}{c}\text { Control year } \\
\text { Control industry }\end{array}$ \\
\hline
\end{tabular}

\subsection{Model Building}

Based on the above analysis, in order to test the impact of management defense on enterprise innovation and the impact of institutional investor research on the relationship between management defense and enterprise innovation, this paper constructs the following model with reference to the research design of Yan Zhenli et al. $(2019)^{[9]}$.

(1) Management defense and the return of enterprise innovation. In order to test hypothesis 1 and 2, we use formula (1) to study the relationship between managerial defense and enterprise innovation.

$$
\begin{aligned}
\operatorname{Ln}\left(1+I_{\left.N N O_{i, t+1}\right)=}\right. & \alpha_{0}+\alpha_{1} \text { MEI }_{i, t}+\alpha_{2} \text { Size }_{i, t}+\alpha_{3} \text { Lev }_{i, t}+\alpha_{4} \text { Roe }_{i, t}+ \\
& \alpha_{5} \text { Growth }_{i, t}+\alpha_{6} \text { Tobin }_{i, t}+\alpha_{7} \text { First }_{i, t}+\alpha_{8} \text { Bsize }_{i, t}+ \\
& \alpha_{9} \text { Age }_{i, t}+\alpha_{10} \text { Industry }_{i}+\alpha_{11} \text { Year }_{i}+\varepsilon
\end{aligned}
$$

\section{Empirical Analysis}

\subsection{Descriptive Statistics}

Descriptive statistics of variables are reported in Table 3. The maximum value of management defense (MEI) is 1.500 , and the minimum value is 0.167 , which indicates that different enterprises have different degrees of management defense. Through the investigation of the average and median of the financial degree of Listed Companies in China, it is found that there is a large gap in the financial degree of Listed Companies in China. The descriptive statistics of other variables were in the

\begin{tabular}{|c|c|c|c|c|c|c|}
\hline & $\mathrm{N}$ & Min & Max & Mean & SD & P50 \\
\hline INNO & 4998 & 0.000 & 7.276 & 3.115 & 1.395 & 3.178 \\
\hline MEI & 4998 & 0.167 & 1.500 & 0.744 & 0.302 & 0.667 \\
\hline Size & 4998 & 20.103 & 26.135 & 22.067 & 1.123 & 21.900 \\
\hline Lev & 4998 & 0.050 & 0.849 & 0.397 & 0.190 & 0.384 \\
\hline Roe & 4998 & -0.325 & 0.270 & 0.066 & 0.070 & 0.064 \\
\hline Growth & 4998 & -0.456 & 2.166 & 0.162 & 0.307 & 0.113 \\
\hline TobinQ & 4998 & 0.940 & 8.738 & 2.312 & 1.241 & 1.944 \\
\hline First & 4998 & 0.085 & 0.748 & 0.342 & 0.138 & 0.327 \\
\hline Bsize & 4998 & 1.792 & 2.708 & 2.153 & 0.165 & 2.197 \\
\hline Age & 4998 & 5.000 & 29.000 & 15.258 & 4.961 & 15.000 \\
\hline
\end{tabular}
normal range.

Table 3 Descriptive Statistics

\subsection{Regression Analysis}

(1)Regression analysis of managerial defense and enterprise innovation.

Table 4 reports the regression results of management defense (MEI) and enterprise innovation (INNO). From the regression results of the whole sample, we can see that the $\mathrm{F}$ value of the model is 64.520 , and the $\mathrm{R} 2$ of the regression is 0.260 , which is significant at the $1 \%$ level, indicating that the construction of the model is feasible, the fitting is good, and the empirical results are reliable The regression coefficient of management defense (MEI) and enterprise innovation (INNO) is - 0.221 , and it is significantly negative at the level of $1 \%$. That is to say, the higher the defense level of the management, the easier the management to carry out self-interest behavior and reduce enterprise innovation, which supports hypothesis 1a. From the grouped regression samples, we can see that the regression coefficient of management defense (MEI) and enterprise innovation (INNO) in the state-owned samples is - 0.485 , which is significantly negative at the $1 \%$ level, and the regression coefficient of 
management defense (MEI) and enterprise innovation (INNO) in the non-state-owned samples is -0.115 , which is significantly negative at the $10 \%$ level, which indicates that the management defense in the state-owned samples and the non-state-owned samples is opposite However, compared with non-state-owned enterprises, the negative impact of state-owned enterprise management defense on enterprise innovation is more significant, which supports hypothesis $1 \mathrm{~b}$.

Table 4 Regression Analysis of managerial defense and enterprise innovation

\begin{tabular}{|c|c|c|c|}
\hline \multirow{2}{*}{ Variable } & Full sample & $\begin{array}{l}\text { State owned } \\
\text { sample }\end{array}$ & $\begin{array}{c}\text { Non state } \\
\text { owned sample }\end{array}$ \\
\hline & $\begin{array}{l}\text { regression } \\
\text { coefficient }\end{array}$ & $\begin{array}{l}\text { regression } \\
\text { coefficient }\end{array}$ & $\begin{array}{l}\text { regression } \\
\text { coefficient }\end{array}$ \\
\hline MEI & $-0.211 * * *$ & $-0.485 * * *$ & $-0.115^{*}$ \\
\hline $\mathrm{CVs}$ & Yes & Yes & Yes \\
\hline Annual effect & Yes & Yes & Yes \\
\hline Industry effect & Yes & Yes & Yes \\
\hline R2 & 0.260 & 0.372 & 0.218 \\
\hline $\mathrm{N}$ & 4998 & 1494 & 3504 \\
\hline
\end{tabular}

The significance level is $1 \%$. The significance level of $* *$ is $5 \%$, and the significance level of $* *$ is $10 \%$.

\section{Conclusion and Suggestion}

With the development of information technology, we should use Internet technology such as blockchain to strengthen the supervision of management defense.Based on the relevant data of non-financial listed companies in A-share market from 2013 to 2017, this paper empirically analyzes the relationship between managerial defense and enterprise innovation, and further examines the differences of the above relationship among enterprises with different property rights, and draws the following conclusions: (1) in order to maintain their positions and maximize their own utility, managers will adopt managerial defense behavior, and managerial defense process is the most important The enhancement of the degree of innovation will inhibit enterprise innovation. (3) Compared with non-state-owned enterprises, the negative correlation between managerial defense and enterprise innovation is more significant.

According to the above research conclusions, this paper puts forward the following policy suggestions: (1) the regulatory department should improve the understanding of management defense, guide enterprises to restrain management defense behavior and improve the innovation ability of enterprises by employing high-level management talents, designing reasonable salary mechanism and equity incentive system, and improving the internal governance structure of the company. (2) Government departments should cultivate and improve the manager market of state-owned enterprises, establish a talent selection system, further deepen the reform of state-owned enterprises, promote the marketization process of China, give full play to the governance role of institutional investor research, restrain the defensive behavior of management, and improve the innovation ability of state-owned enterprises.

\section{References}

1. Morck Randall,Shleifer Andrei, Vishny Robert W.(1988) Management ownership and market valuation : An empirical analysis. Journal of Financial Economics, 20 (88):293-315.

2. Huang Guoliang, Yang Guang.(2018) Management defense, product market competition and $\mathrm{R} \& \mathrm{D}$ investment of enterprises. Accounting communication, (33): 82-84+102+129

3. Wu Jianxiang, Li Bingxiang.(2017) Management defense and risk bearing level of enterprises: the regulatory role of equity incentive. Economic longitude, 34 (05): 104-108

4. Wang Bing, Bao Shengying, Kan Jinghua.(2017) Can state audit restrain excessive investment of state-owned enterprises?. Accounting research, (09): 83-89+97

5. Zhang M , Lijun M , Zhang B , et al.(2016) Pyramidal structure, political intervention and firms' tax burden: Evidence from China's local SOEs. Journal of Corporate Finance, 36:15-25.

6. Shleifer A,Vishny R W.A.(1997) Survey of Corporate Governance.The Journal of Finance, 52 (2):737-783.

7. Li Bingxiang, Liu Shuxin, Chen Ying.(2018) Research on the influence of managerial defense on the choice of financial asset classification accounting policy -- Based on the moderating effect of separation of two rights. Economic and management review, 34 (01): 82-95

8. Zhou Donghua, Huang Jia, Zhao Yujie.(2019) Employee stock ownership plan and enterprise innovation. Accounting research, (03): 63-70

9. Yan Zhenli, Liang Shangkun, Yuan Chun. (2019) Vertical concurrent management, institutional environment and enterprise innovation. Economic management, 41 (10): 90-107 